\title{
Delaware's Forest Resources, 2009
}

This publication provides an overview of forest resource attributes for Delaware based on an annual inventory conducted by the Forest Inventory and Analysis (FIA) program at the Northern Research Station of the U.S. Forest Service. These estimates, along with web-posted core tables, will be updated annually. For more information please refer to page 4 of this report.

Table 1. - Annual estimates, uncertainty, and change.

\begin{tabular}{|c|c|c|c|}
\hline & Estimate & $\begin{array}{l}\text { Sampling } \\
\text { error }(\%)\end{array}$ & $\begin{array}{l}\text { Change } \\
\text { since } \\
2008(\%)\end{array}$ \\
\hline \multicolumn{4}{|l|}{ Forest Land Estimates } \\
\hline Area $(1,000$ acres $)$ & 345 & 4.2 & -2.0 \\
\hline $\begin{array}{l}\text { Number of live trees 1-inch } \\
\text { diameter or larger (million trees) }\end{array}$ & 245 & 9.0 & 1.1 \\
\hline $\begin{array}{l}\text { Dry biomass of live trees } 1 \text {-inch } \\
\text { diameter or larger (1,000 tons) }\end{array}$ & 23,757 & 5.6 & 0.6 \\
\hline $\begin{array}{l}\text { Net volume in live trees } \\
\left(1,000,000 \mathrm{ft}^{3}\right)\end{array}$ & 872 & 61.1 & 1.1 \\
\hline $\begin{array}{l}\text { Annual net growth of growing-stock } \\
\text { trees }\left(1,000 \mathrm{ft}^{3} / \text { year }\right)^{\star}\end{array}$ & 35,672 & 12.9 & $\mathrm{~N} / \mathrm{A}$ \\
\hline $\begin{array}{l}\text { Annual mortality of growing-stock } \\
\text { trees }\left(1,000 \mathrm{ft}^{3} / \text { year }\right)^{\star}\end{array}$ & 5,985 & 23.1 & $\mathrm{~N} / \mathrm{A}$ \\
\hline $\begin{array}{l}\text { Annual removals of growing-stock } \\
\text { trees }\left(1,000 \mathrm{ft}^{3} / \text { year }\right)^{*}\end{array}$ & 7,555 & 54.2 & $\mathrm{~N} / \mathrm{A}$ \\
\hline \multicolumn{4}{|l|}{ Timberland Estimates } \\
\hline Area $(1,000$ acres $)$ & 337 & 4.5 & -2.3 \\
\hline $\begin{array}{l}\text { Number of live trees 1-inch } \\
\text { diameter or larger (million trees) }\end{array}$ & 241 & 9.1 & 2.8 \\
\hline $\begin{array}{l}\text { Dry biomass of live trees } 1 \text {-inch } \\
\text { diameter or larger (1,000 tons) }\end{array}$ & 22,644 & 5.8 & -1.4 \\
\hline $\begin{array}{l}\text { Net volume in live trees } \\
\left(1,000,000 \mathrm{ft}^{3}\right)\end{array}$ & 822 & 6.1 & -2.0 \\
\hline $\begin{array}{l}\text { Net volume of growing-stock trees } \\
\left(1,000,000 \mathrm{ft}^{3}\right)\end{array}$ & 792 & 6.2 & -2.2 \\
\hline $\begin{array}{l}\text { Annual net growth of growing-stock } \\
\text { trees }\left(1,000 \mathrm{ft}^{3} / \text { year }\right)^{\star}\end{array}$ & 31,330 & 12.4 & $\mathrm{~N} / \mathrm{A}$ \\
\hline $\begin{array}{l}\text { Annual mortality of growing-stock } \\
\text { trees }\left(1,000 \mathrm{ft}^{3} / \text { year }\right)^{\star}\end{array}$ & 4,523 & 25.3 & $\mathrm{~N} / \mathrm{A}$ \\
\hline $\begin{array}{l}\text { Annual removals of growing-stock } \\
\text { trees }\left(1,000 \mathrm{ft}^{3} / \text { year }\right)^{\star}\end{array}$ & 6,899 & 55.0 & $\mathrm{~N} / \mathrm{A}$ \\
\hline
\end{tabular}

* Growth, removals and mortality data are based on changes from the 1999 to 2008 remeasurement data.

Note: When available, sampling errors/bars provided in figures and tables represent 68 percent confidence intervals.

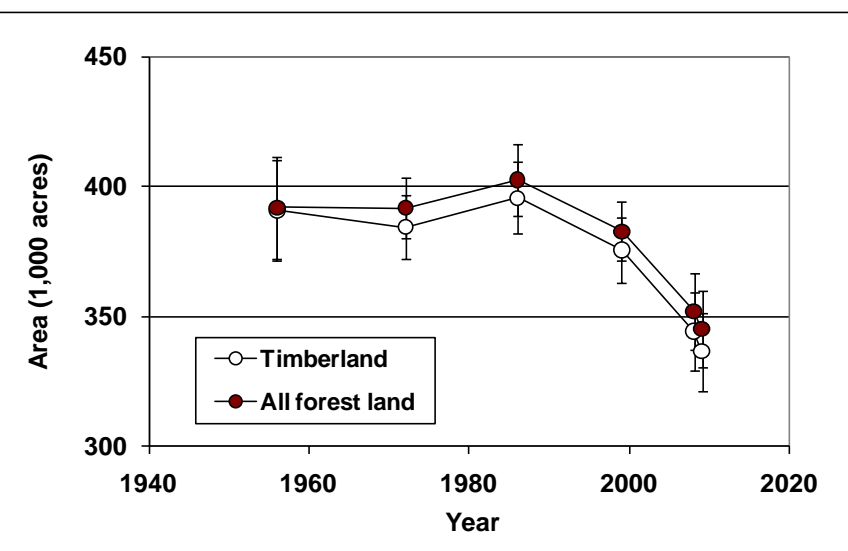

Figure 1. - Area of timberland and forest land by year.

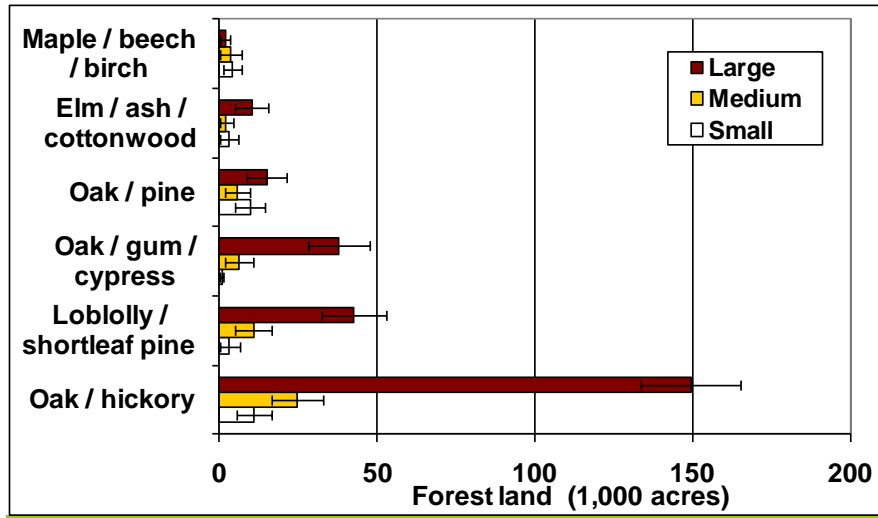

Figure 2. - Area of forest land area by top six forest type groups and stand size class, 2005-2009.

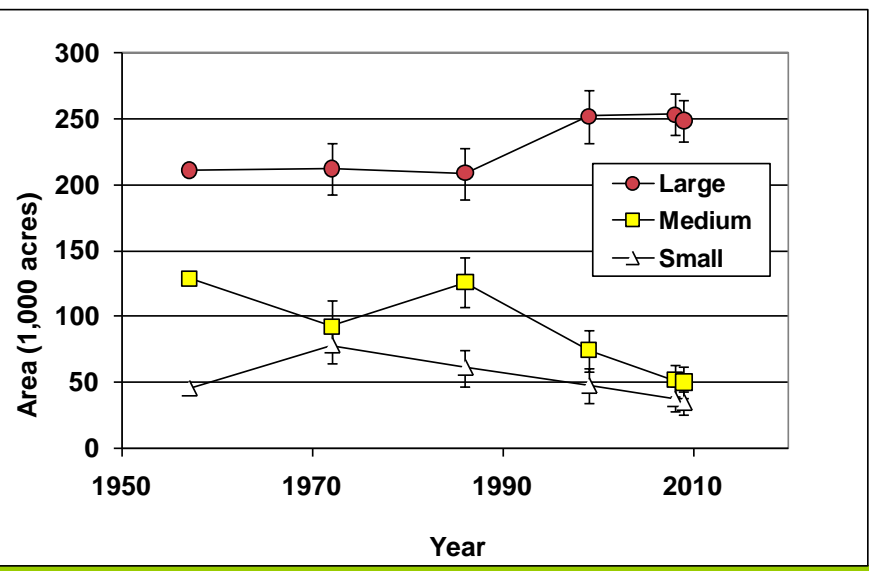

Figure 3. - Area of timberland by stand size class and year. 


\begin{tabular}{|c|c|c|c|c|c|c|c|}
\hline Rank & Species & $\begin{array}{c}\text { Volume of live trees } \\
\text { on forest land } \\
\left(1,000,000 \mathrm{ft}^{3}\right)\end{array}$ & $\begin{array}{c}\text { Sampling } \\
\text { error } \\
(\%)\end{array}$ & \begin{tabular}{|c|} 
Change \\
since 2008 \\
$(\%)$ \\
\end{tabular} & $\begin{array}{c}\text { Volume of sawtimber } \\
\text { trees on timberland } \\
(1,000,000 \text { bdft })\end{array}$ & \begin{tabular}{|c|} 
Sampling \\
error \\
$(\%)$
\end{tabular} & \begin{tabular}{|c|} 
Change \\
since 2008 \\
$(\%)$ \\
\end{tabular} \\
\hline 1 & Red maple & 192 & 11.9 & \begin{tabular}{|l|}
1.6 \\
\end{tabular} & 583 & 16.4 & 4.3 \\
\hline 2 & Loblolly pine & 113 & 18.5 & 14.9 & 388 & 20.2 & 19.0 \\
\hline 3 & Sweetgum & 108 & 13.5 & -5.7 & 321 & 17.2 & -10.6 \\
\hline 4 & Yellow-poplar & 106 & 27.1 & 11.7 & 309 & 27.6 & -25.3 \\
\hline 5 & White oak & 65 & 17.5 & -0.3 & 265 & 20.8 & -0.8 \\
\hline 6 & Willow oak & 40 & 32.7 & -2.0 & 196 & 34.3 & -2.0 \\
\hline 7 & Blackgum & 32 & 19.7 & -6.5 & 81 & 28.8 & -10.0 \\
\hline 8 & Southern red oak & 28 & 23.2 & -6.8 & 97 & 26.7 & -7.5 \\
\hline 9 & Scarlet oak & 24 & 31.1 & 8.5 & 94 & 34.6 & 6.6 \\
\hline \multirow[t]{4}{*}{10} & Virginia pine & 20 & 30.1 & -19.4 & 71 & 36.4 & -22.1 \\
\hline & Other softwoods & 2 & 95.4 & 0.0 & 4 & 115.9 & 10.0 \\
\hline & Other hardwoods & 144 & 12.4 & -3.4 & 396 & 18.3 & 0.0 \\
\hline & All species & 872 & 6.1 & 1.1 & 2,806 & 7.8 & -3.2 \\
\hline
\end{tabular}
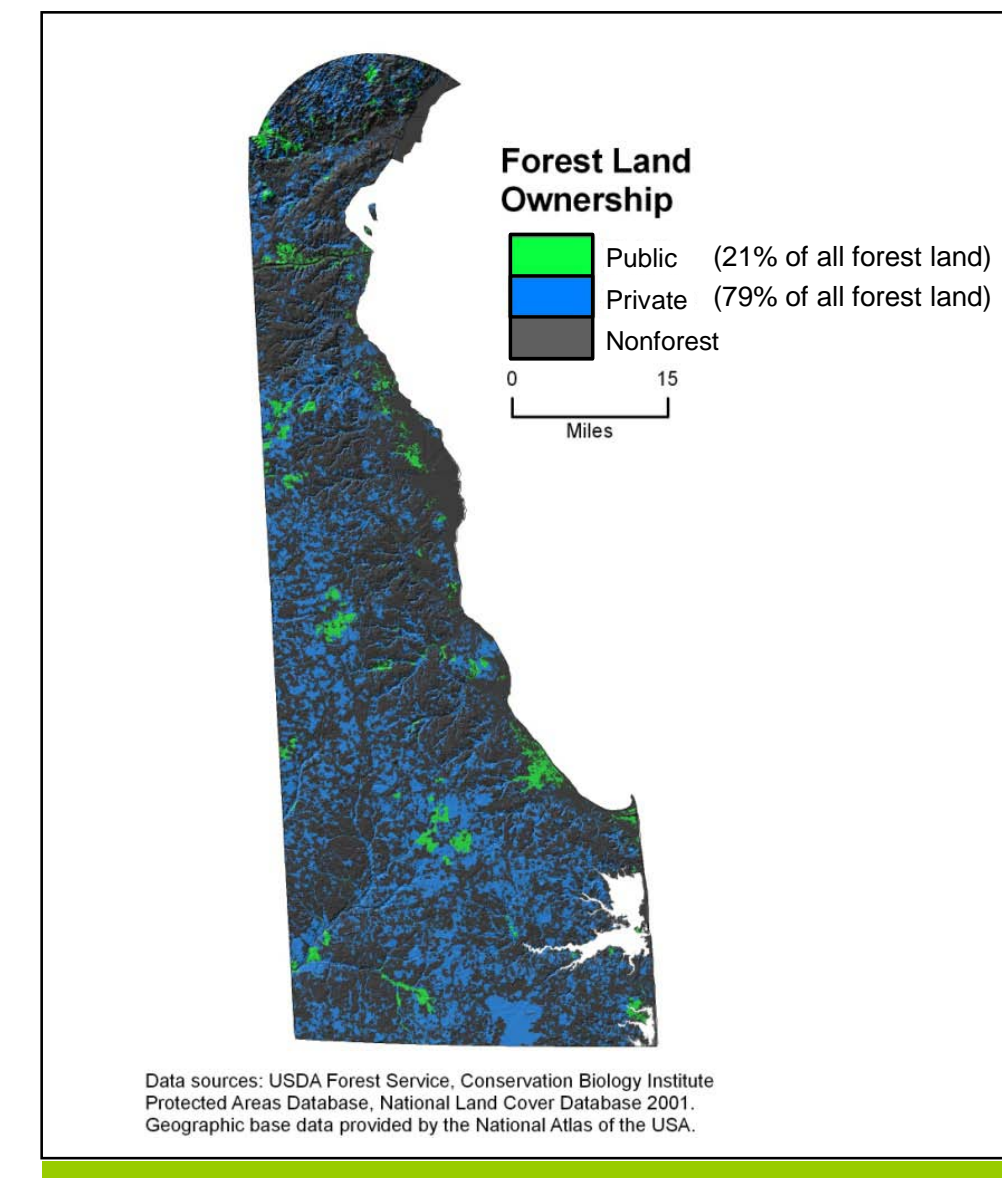

\section{Acres of forest land}

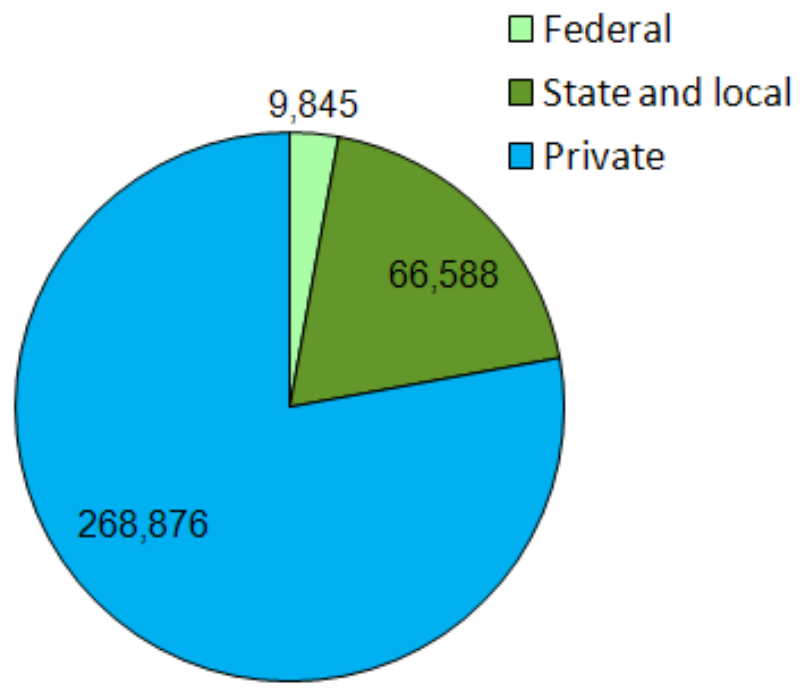

Data sources: USDA Forest Service, Conservation Biology Institute

Protected Areas Database, National Land Cover Database 2001.

Geographic base data provided by the National Atlas of the USA.

Figure 4. - Distribution of ownerships and area of forest land (acres) by ownership group, Delaware, 2005-2009. 


\section{Decreasing Abundance of Loblolly Pine}

Loblolly pine was once the most prevalent species in Delaware in terms of both volume and number of trees. Historically, loblolly pine, which grows mostly in the southern portion of the state (Fig. 5), has been an important commercial species in Delaware. In the last few years, however, several mills have closed and now the majority of loblolly pulp and timber is processed in mills outside the state.

Overall, Delaware has experienced a gradual loss in forest area and a decrease in the total number of trees for the last several decades. The decrease in the number of loblolly pine trees, however, has outpaced that of the overall tree population - 64 percent versus 14 percent respectively, since 1986 . This trend can be observed in both natural and planted stands (Fig.6).

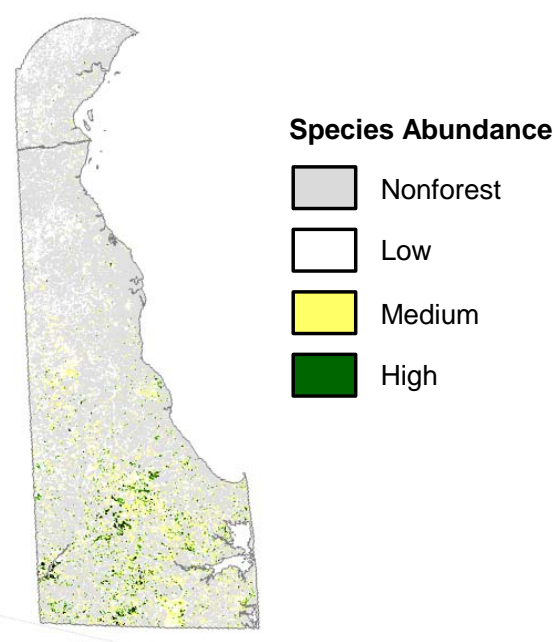

Figure 5. - Distribution of loblolly pine in Delaware.

Through the 1980s there was more loblolly pine volume in Delaware forests than any other tree species. Trends in forest inventory data indicate that around 1990, red maple surpassed loblolly pine in total volume (Fig. 7). However, data from the 2009 inventory in Delaware suggest that the decline in loblolly pine and the increase in red maple volume may have stabilized. These changes may be due in part to changes in land development rates, ecological succession patterns, or forest management practices (e.g., the passage of the Delaware Seed Tree Law [Title 3, Chapter 10, Subchapter V]).

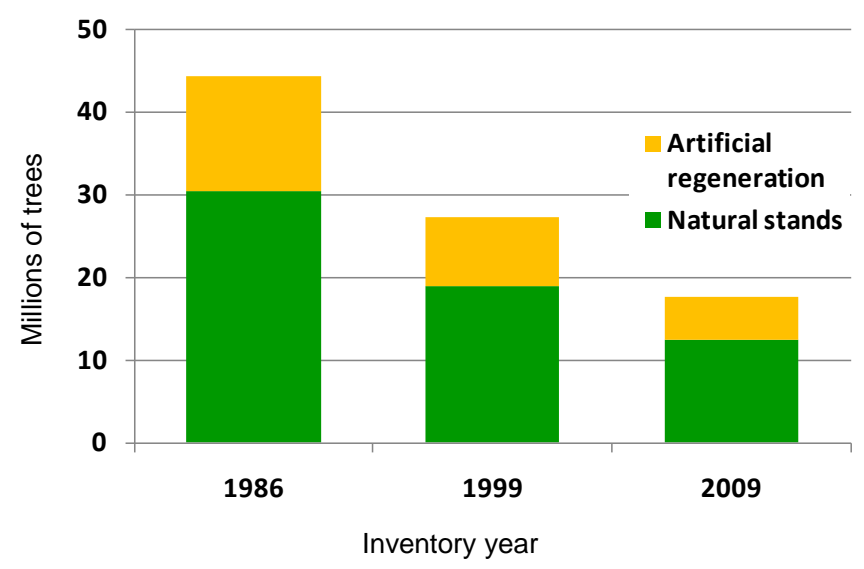

Figure 6. - Number of loblolly pine trees in Delaware by year and origin of regeneration.

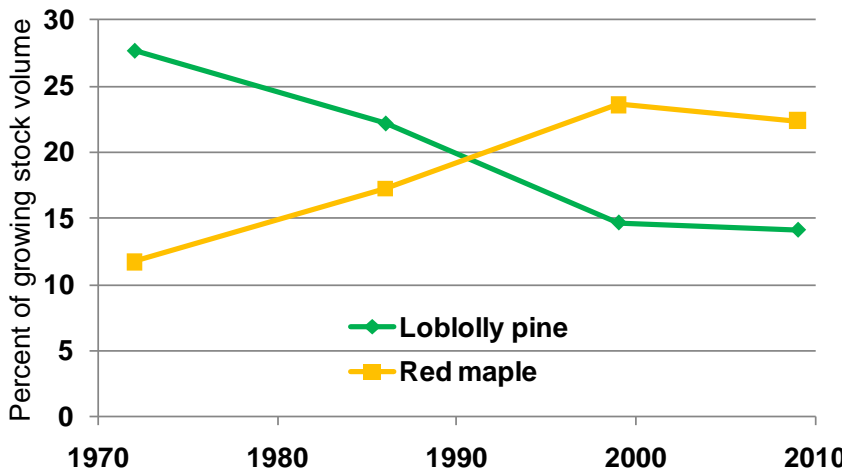

Figure 7. - Trends in loblolly pine and red maple growing stock volume relative to total growing stock volume in Delaware 1972-2009. 


\section{Citation for this Publication}

Lister, T.W.; Gladders, G. 2011. Delaware's forest resources, 2009. Res. Note NRS-86. Newtown Square, PA: U.S. Department of Agriculture, Forest Service, Northern Research Station. 4 p.

\section{FIA Program Information}

Bechtold, W.A.; Patterson, P.L., eds. 2005. The enhanced Forest Inventory and Analysis program: national sampling design and estimation procedures. Gen. Tech. Rep. SRS-80. Asheville, NC: U.S. Department of Agriculture, Forest Service, Southern Research Station. 85 p.

Smith, W.B. 2002. Forest Inventory and Analysis: a national inventory and monitoring program. Environmental Pollution. 116: $233-242$.

USDA Forest Service. 2005. Forest inventory and analysis national core field guide, Vol. 1, field data collection procedures for phase 2 plots, Ver. 3.0. Available at http://www.fia.fs.fed.us/library/field-guides-methods-proc/ (verified Aug. 1, 2008).

\section{Additional Delaware Inventory Information}

Ferguson, R.H. 1959. The timber resources of Delaware. A report on the forest survey made by the U.S. Forest Service. Upper Darby, PA: U.S. Department of Agriculture, Forest Service, Northeastern Forest Experiment Station. 30 p.

Ferguson, R.H.; Mayer, Carl E. 1974. The timber resources of Delaware. Resour. Bull. NE-32. Upper Darby, PA: U.S. Department of Agriculture, Forest Service, Northeastern Forest Experiment Station. 42 p.

Frieswyk, T.S.; DiGiovanni, D.M. 1989. Forest statistics for Delaware-1972 and 1986. Resour. Bull. NE-109. Broomall, PA: US. Department of Agriculture, Forest Service, Northeastern Forest Experiment Station. 86 p.

Griffith, D.M.; Widmann, R.H. 2001. Forest statistics for Delaware: 1986 and 1999. Resour. Bull. NE-151. Newtown Square, PA: U.S. Department of Agriculture, Forest Service, Northeastern Research Station. 58 p.

Lister, T.W.; Gladders, G; Butler, B.; Barnett, C.; O'Connell, B. 2010. Delaware's forest resources, 2008. Res. Note NRS71. Newtown Square, PA: U.S. Department of Agriculture, Forest Service, Northern Research Station. 4 p.

\section{Contact Information}

Lead Analyst: Tonya Lister (610) 557-4033, tlister01@fs.fed.us

Data processing/access: Chuck Barnett, (610) 557-4037, cjbarnett@fs.fed.us

Field data collection: Tom Willard, (717) 718-7881, thomaswillard@fs.fed.us

Estimates, tabular data, and maps from this report may be generated at: www.fiatools.fs.fed.us

The U.S. Department of Agriculture (USDA) prohibits discrimination in all its programs and activities on the basis of race, color, national origin, age, disability, and where applicable, sex, marital status, familial status, parental status, religion, sexual orientation, genetic information, political beliefs, reprisal, or because all or part of an individual's income is derived from any public assistance program (Not all prohibited bases apply to all programs.) Persons with disabilities who require alternate means for communication of program information (Braille, large print, audiotape, etc.) should contact USDA's TARGET Center at (202) 720-2600 (voice and TDD). To file a complaint of discrimination, write to USDA, Director, Office of Civil Rights, 1400 Independence Avenue, S.W., Washington, DC 20250-9410, or call (800)795-3272 (voice) or (202)720-6382 (TDD). USDA is an equal opportunity provider and employer. 